\title{
Brussels reshapes science panels after BSE criticism
}

[PARIS] As part of an overhaul of its system for gathering scientific advice on food and health issues, the European Commission in Brussels last week announced details of how it plans to reorganize its advisory committees.

It hopes these changes will help to restore public confidence in an advisory system whose image has been badly tarnished by the commission's failure to prevent the crisis over bovine spongiform encephalopathy (BSE). Advisory committees, and the commission itself, have been criticized for allegedly paying too much attention to national and economic interests to the detriment of consumer safety (see Nature 385, 6; 1997).

The reorganization of the advisory committees is similar to that promised earlier this year by the commission's president, Jacques Santer (see Nature 385, 664; 1997). The six committees covering food and public health have been moved from the industry and agriculture directorates to the consumer directorate, under a scientific steering committee that will coordinate their work.

The steering committee will be chaired by

Fritz Kemper, a virologist from the University of Münster in Germany, and will include the chairpersons of the six advisory committees and eight outside experts.

Minutes of advisory committee meetings, including details of minority positions, will in future be made public, a measure broadly welcomed by consumer organizations. But these organizations are unhappy that responsibility for setting policy and proposing legislation on food safety will remain with the agriculture and industry directorates, which also look after the interests of industry and agriculture.

Jim Murray, director of the European federation of consumer organizations (BEUC), in a letter to Santer, argues that "without a clear separation of [these] functions, conflicts of interest will continue to arise".

Rachel Kenningham, an official with the UK Consumer Association, says that a better system would have been to give executive powers to the consumer directorate that would have allowed it to propose legislation and codes of practice.

But Kenningham, like many other observers, feels that the changes, which will

\section{Britain extends controls to combat risk to sheep}

[PARIS] The British government last week announced that it is to extend strict bovine spongiform encephalopathy (BSE) controls to sheep, to guard against the risk that the disease has jumped to sheep and is coexisting in flocks alongside scrapie.

The new measures, which were announced by the agriculture minister, Jack Cunningham, include removal in the abattoir of the spinal cord from sheep and goats over one year of age, and the spleen from all animals heads are already banned from human consumption and animal feed.

The risk that sheep have acquired BSE from contaminated animal feed was raised by the government's Spongiform Encephalopathy Advisory Committee. Oral transmission of BSE to sheep has been demonstrated experimentally, despite no evidence for its existence in the field. Cunningham said the government was taking "sound, precautionary measures" to avoid any possible risk to consumers, "no matter how remote". Similar controls have been introduced in France, Ireland and the Netherlands.

But European Commission proposals for controls on sheep throughout the European Union, as recommended by its scientific veterinary committee, have been repeatedly rejected by the council of farm ministers, with several countries arguing that they do not have BSE (see Nature 384, 8; 1996).

In a separate move, the

British government is threatening to ban the import of beef from countries with BSE unless they bring their controls up to UK standards.

The European

Commission says such a unilateral move would be illegal. But Britain is finding sympathy in some quarters. "Cunningham's move is extremely sensible," says one European Parliament official.

Britain is also likely to find ammunition for its demands in a paper submitted to the Veterinary Record suggesting that BSE has been underreported in countries on the continent, and that the approximately 50 declared cases are fewer than the several thousand expected, given the level of exports of contaminated animal feed and cattle (see Nature 382, 4; 1996).

The findings, from an international research group led by Bram Schreuder from the Dutch DLO-Institute for Animal Science and Health in Lelystad, are likely to weaken the position of Germany and other countries who oppose stricter BSE controls on the grounds that they have no BSE.

D. B.

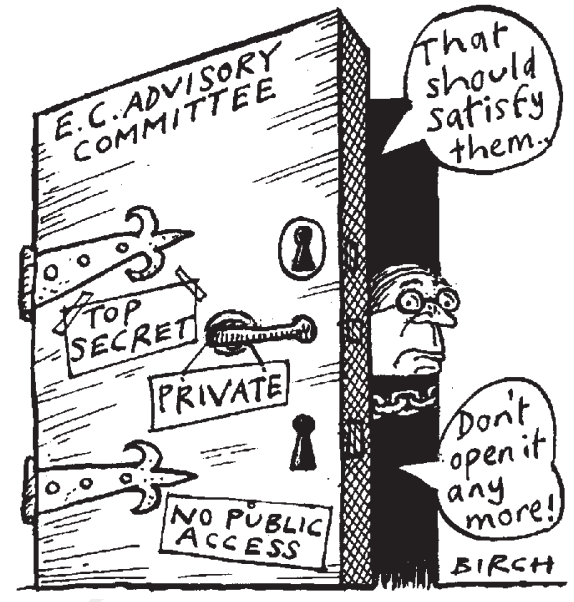

take effect next month, represent significant progress. They argue that allocating responsibility for scientific advice to a strengthened consumer directorate, combined with greater openness and independence of advisory committees, will expose decisions on scientific issues to more public scrutiny. "At least the decision-making will now be in daylight and not behind closed doors," says one advisory committee member .

One major change concerns the nomination of experts to the committees. Until now the selection procedure has been opaque, leading to questions about the competence and independence of nominees, and the criteria on which they were appointed.

The commission now intends to recruit experts through an open competition, or concours. Candidates will be assessed by a selection panel of commission officials chaired by an eminent scientist, with observers from the European Parliament and the Council of Ministers present.

The commission will then nominate experts from the panel's shortlist. All candidates will be required to declare any potential conflicts of interest.

But there could be a drawback. One commission official argues that eminent scientists often feel that it is "beneath" them to have to apply for appointments through a procedure akin to that used for recruiting junior civil servants. Several have already complained, according to the official, who added that as a result the commission risks recruiting "mediocre" experts.

The European Parliament has warned that if the commission has not implemented sufficient reforms by the end of the year, it will consider using its powers to vote a motion of censure. All the commissioners would then be dismissed.

The BSE crisis might have been avoided if there had been greater openness in its handling in Brussels, says one member of the commission's scientific veterinary committee. He claims that the 30 or so meetings of the committee on BSE produced a mass of information and debate, little of which reached the public domain.

DeclanButler 